\title{
Quantifying biodiversity impacts of climate change and bioenergy: the role of integrated global scenarios
}

\author{
Laura Meller • Detlef P. van Vuuren • \\ Mar Cabeza
}

Received: 4 March 2013/ Accepted: 27 June 2013/Published online: 12 July 2013

(C) Springer-Verlag Berlin Heidelberg 2013

\begin{abstract}
The role of bioenergy in climate change mitigation is a topic of heated debate, as the demand for land may result in social and ecological conflicts. Biodiversity impacts are a key controversy, given that biodiversity conservation is a globally agreed goal under pressure due to both climate change and land use. Impact assessment of bioenergy in various socio-economic and policy scenarios is a crucial basis for planning sound climate mitigation policy. Empirical studies have identified positive and negative local impacts of different bioenergy types on biodiversity, but ignored indirect impacts caused by displacement of other human activities. Integrated assessment models (IAMs) provide land-use scenarios based on socioeconomic and policy storylines. Global scenarios capture both direct and indirect land-use change, and are therefore an appealing tool for assessing the impacts of bioenergy on biodiversity. However, IAMs have been originally designed to address questions of a different nature. Here, we illustrate the properties of IAMs from the biodiversity conservation perspective and discuss the set of questions they could answer. We find IAMs are a useful starting point for more detailed regional planning and assessment. However, they have important limitations that should not
\end{abstract}

L. Meller $(\bowtie) \cdot$ M. Cabeza

Metapopulation Research Group, Department of Biosciences, P.O. Box 65, 00014 University of Helsinki, Finland

e-mail: laura.meller@helsinki.fi

D. P. van Vuuren

PBL Netherlands Environmental Assessment Agency, Bilthoven, The Netherlands

D. P. van Vuuren

Department of Geosciences, Utrecht University,

Utrecht, The Netherlands be overlooked. Global scenarios may not capture all impacts, such as changes in forest habitat quality or smallscale landscape structure, identified as key factors in empirical studies. We recommend increasing spatial accuracy of IAMs through region-specific, complementary modelling, including climate change into predictive assessments, and considering future biodiversity conservation needs in assessments of impacts and sustainable potentials of bioenergy.

Keywords Adaptation - Biodiversity · Bioenergy · Conservation · Impact assessment · Mitigation

\section{Conserving biodiversity in times of global change}

Biological diversity is declining rapidly all around the world, despite global conventions and increased conservation efforts (Butchart et al. 2010). The main causes of this decline include habitat loss and degradation, overharvesting, pollution and invasive species; in addition, climate change is expected to exacerbate the pressure on biodiversity (Millennium Ecosystem Assessment 2005). The impacts of climate change are already evident across a wide range of species and habitats (Bellard et al. 2012; Chen et al. 2011; Parmesan 2006). As even the most ambitious climate policies are only expected to mitigate climate change, enhanced conservation action is required. Suggested strategies to adapt conservation to the climate challenge include better connected, more numerous and larger protected areas (Hannah et al. 2007; Heller and Zavaleta 2009; Hodgson et al. 2009), and management practices that allow for persistence and dispersal of species in the landscape outside protected areas (Hannah et al. 2002; Noss, 2001). 
While climate change mitigation is required to reduce its future impact on biodiversity (Dawson et al. 2011; Heller and Zavaleta 2009), mitigation action should be planned with biodiversity in mind: some activities for reducing greenhouse emissions could themselves be harmful for biodiversity (Paterson et al. 2008). For example, hydropower dams may potentially help to decarbonize the energy sector, but their impacts on local biodiversity may be severe (Nilsson and Berggren 2000). Also afforestation could, depending on the form, have negative impacts on native flora and fauna: if based on tree plantations, naturally open habitats could be replaced by low-biodiversity ecosystems with high water uptake (Jackson et al. 2005). Other activities have been identified as beneficial for both climate change mitigation and biodiversity conservation. An example of such win-win strategies would be conservation of primary forests along with their carbon stores and sinks as well as their high biodiversity value (Righelato and Spracklen 2007).

Bioenergy is considered to be an important alternative for fossil fuels. Most models therefore project a rapid increase in bioenergy use in mitigation scenarios (IPCC 2011; Rose et al. 2012; van Vuuren et al. 2010). In particular, scenarios aiming to limit the increase in annual mean temperature below 2 degrees compared to preindustrial times (UNFCCC 2010) are expected to increase bioenergy demand (van Vuuren et al. 2010) given the key role of negative emissions in the second half of the century using bio-energy and carbon capture and storage (BECCS).

Increased use of bioenergy may lead to conflicts with food security, water availability and biodiversity conservation (Dornburg et al. 2012), which makes the sustainability of bioenergy a subject for heated debate. Integrated assessment models (IAMs) of climate and land-use change can be used to assess global bioenergy potentials in different socio-economic scenarios and under various constraints. However, these models do not account for specific local, regional and landscape-scale opportunities and constraints that are important for assessing the impacts of bioenergy-related land-use change (Davis et al. 2011) and for mitigating the negative impacts from bioenergy (Gaucherel et al. 2009). Furthermore, the mitigation effect of bioenergy depends on the source, and may be significantly reduced or even be multifold exceeded by emissions from associated land-use changes (Fargione et al. 2008). Indeed, Creutzig et al. (2012) identify a need to integrate knowledge from empirical and inductive life cycle studies into IAMs to better understand potential, uncertainty and risks of direct and indirect land-use impacts. From the perspective of biodiversity conservation, the important question is how increased bioenergy supply affects the availability and quality of habitats for species as well as spatial conservation opportunities. Understanding the impacts of both climate change and mitigation action is necessary for planning proactive biodiversity conservation and planning sound energy policy.

In this article, we discuss the level of detail and essential indicators needed ideally for model outcomes to be relevant to biodiversity impact assessments. A key aspect here is the different types of questions that are raised regarding the relationship between bioenergy and biodiversity. Some of the questions can be best answered at the global level (e.g. the overall implications of bioenergy for energy systems); others involve factors that can best be handled at a less aggregated scale (e.g. detailed biodiversity impacts). We evaluate whether currently available predictive landuse tools meet those requirements and discuss the role of IAMs in assessing the impacts of bioenergy policy on conservation. Our aim is to provide inspiration for further development and use of IAMs from a conservation scientists' perspective. Furthermore, we offer guidance for using global land-use scenarios in bioenergy impact assessment and policy planning. We start by providing an overview of how land-use scenarios currently assess the impact of bioenergy. We continue with a discussion on why and how modelling studies could be more strongly linked with empirical bioenergy impact studies. Finally, we conclude and provide recommendations.

\section{Land-use scenarios: balancing between geographic coverage and level of detail}

Various types of models can predict how socio-economic or policy scenarios translate into resource demand and supply, and thereby land-use change (Table 1). Clearly, the focal question and spatial scale should determine the choice of methodologies used in any given study. On one hand, bioenergy scenarios have been used in regional biodiversity assessments for croplands (Meehan et al. 2010) and for extraction of fine woody debris (Dahlberg et al. 2011), but these studies typically pay no attention to the wider context such as total energy demand or indirect land use. Studies have shown that this wider context and, in particular, indirect effects may substantially affect the carbon balance (Plevin et al. 2010) and the sustainability of bioenergy (Dornburg et al. 2010; Searchinger et al. 2009). Bioenergy scenarios should thus account for such indirect land-use changes.

On the other hand, there are IAM studies that typically focus on the more aggregated level. IAMs have been developed for climate and energy policy support since late 1980s (Parson and Fisher-Vanden 1997). At present, they are the most important tools for quantifying and assessing scenarios for socio-economic development and policy in the climate change mitigation and adaptation context. Such 
IAMs consist of quantified relationships between human population and activity, climate, land cover and ecosystems (Moss et al. 2010) and enable scenarios for emission reductions, cost-benefit analyses for mitigation options, and simulating feedbacks between climate and land use. As IAMs model emissions and land use simultaneously, they can address also the indirect land-use change arising from bioenergy production. IAMs have been used at global level (van Vuuren et al., 2010) to explore land-use changes in various sets of socio-economic scenarios up to the year 2100 (Rose et al. 2012; Thomson et al. 2011; van Vuuren et al. 2011; van Vuuren et al. 2010; van Vuuren et al. 2006a; Wise et al. 2009). At a European scale, an IAM has been used in combination with a biofuel crop allocation model that accounted for logistics between fields and refineries (Hellmann and Verburg 2011), extending up to year 2030. IAM projections have also been used in biodiversity assessments, for instance, to assess the general pressure of land-use change (Visconti et al. 2011) and even specifically to assess bioenergy impacts (Alkemade et al. 2009; Eggers et al. 2009; Hellmann and Verburg 2010; OECD 2012).

One key set of global land-use projections has been based on the storylines of the so-called SRES scenarios (a set of scenarios developed for the IPCC; IPCC 2000). While these scenarios capture a wide range of possible developments, a downside of them is that they assume development in the absence of policy that specifically targets climate change mitigation, and all of them fail meeting the 2 degrees climate target agreed by the United Nations Framework Convention on Climate Change (UNFCCC 2010). The set of scenarios developed by the IAM framework IMAGE (MNP 2006) for other environmental assessments, and in particular the Millennium Ecosystem Assessment (2005), partly filled this gap. Several international biodiversity assessments have been based on these scenarios (CBD 2010; Pereira et al. 2010; van Vuuren et al. 2006b). More recently, several models have developed scenarios that account for climate and energy policy providing a wide set of land-use scenarios relevant to global climate policy goals (Hurtt et al. 2011; Moss et al. 2010; van Vuuren et al. 2011).

\section{Linking empirical studies with modelling studies}

Biodiversity impact assessments have been undertaken both with empirical studies and with the use of models. In general, empirical studies have a more local focus than modelling studies. Because of this difference in focus, empirical studies use different indicators to quantify impacts than modelling studies.

The main issue covered with empirical studies is the number and abundances of species in bioenergy plots as compared to a reference habitat (e.g. Brin et al. 2012; 
Danielsen et al. 2009; Dhondt et al. 2004; Fry and Slater 2011; Rowe et al. 2011). Findings show that bioenergy impacts depend on the type of bioenergy (Harrison and Berenbaum 2012; Haughton et al. 2009; Myers et al. 2012; Questad et al. 2011; Robertson et al. 2011a, 2012; Werling et al. 2011), management activities (Myers et al. 2012), reference habitat (Felten and Emmerling 2011; Questad et al. 2011) and landscape structure (Baum et al. 2012; Robertson et al. 2011b, 2013; Fig. 1).

Modelling studies, in contrast, mostly focus on the extent and impact of habitat change associated with bioenergy production, in terms of suitable habitat for specific species (Eggers et al. 2009; Louette et al. 2010), the replacement of pristine habitats (Alkemade et al. 2009) and the loss of high nature value habitats (Hellmann and Verburg 2010; see Table 1 for summary). Typically, biodiversity indicators in these studies remain at a superficial level, thereby potentially overlooking important considerations of spatial and population ecology, which may lead to misleading conclusions. Stronger links between the empirical studies and future scenarios could be established by quantifying the relationship between habitat quality and species occurrence or abundance. Appropriate methods for such analysis include correlative species distribution models (Franklin 2009) as well as patch occupancy models based on population dynamics (Hanski and Ovaskainen 2003). Key variables for such predictive analyses should be derived from the empirical evidence base. Ideally, predictions about the distribution of specified bioenergy types, habitat diversity and heterogeneity, as well as structure and distribution of forest biomass would form the basis of predictive impact assessment (Fig. 1).

The conclusions of a scenario analysis of policy outcome are by and large determined by the reference

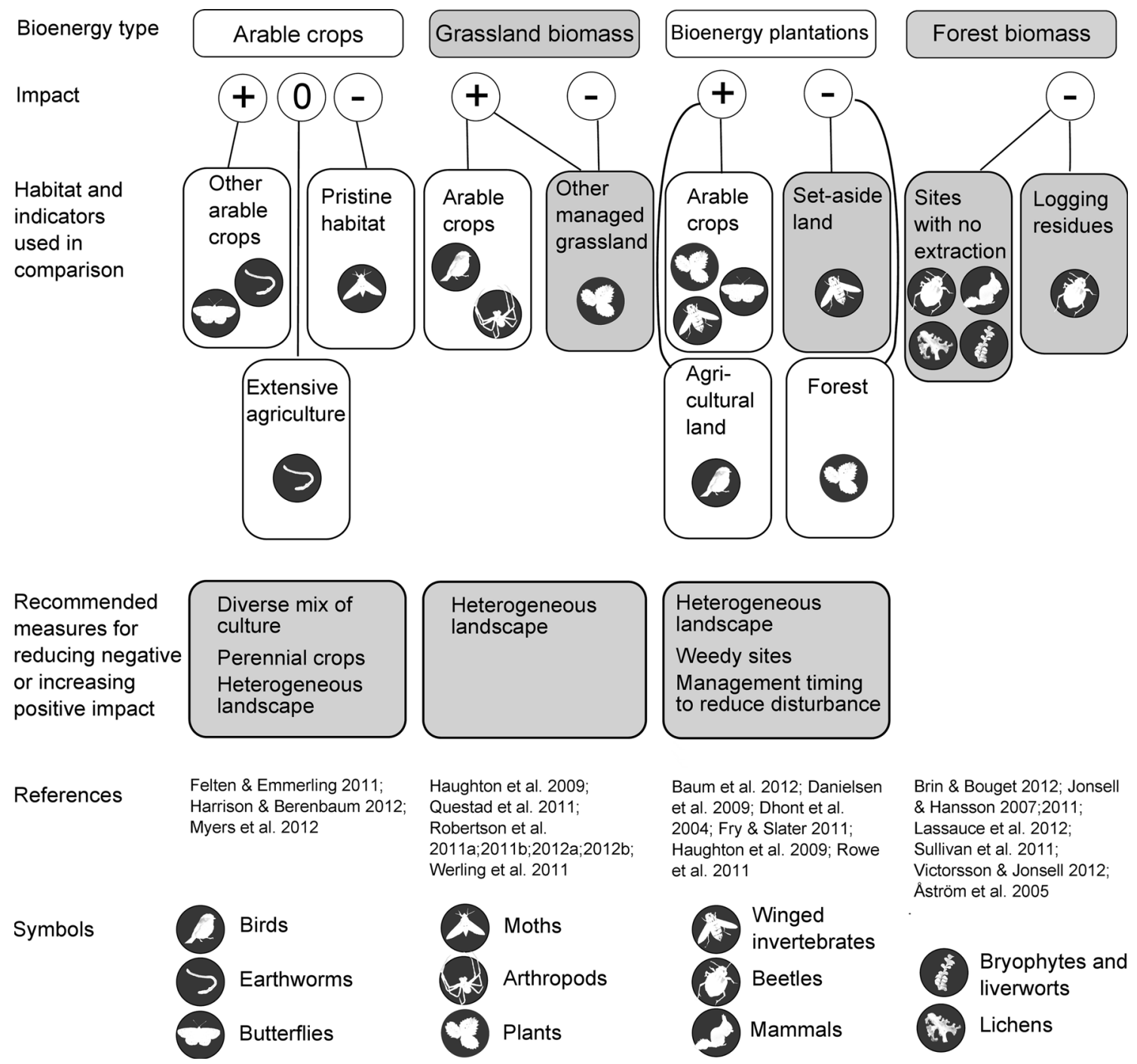

Fig. 1 Examples of recent empirical studies addressing biodiversity in bioenergy feedstock production sites in comparison with a reference landuse type. Grey boxes represent feedstock types, impacts or recommendations that cannot be addressed with current global land-use scenarios 
scenario, where assumptions are made about development in the absence of the policy in question. As regards bioenergy policy, the reference scenario would include landuse trends and climate change trends in the absence of bioenergy use. For instance, the evaluation of bioenergy impacts is very different depending on the reference scenario assumptions of whether land would otherwise be reforested or remain as degraded grassland. Also climate change is expected to have substantial impact on future biodiversity (Barbet-Massin et al. 2012; Bellard et al. 2012; Garcia et al. 2011; Thuiller 2004). Therefore, impact assessments which do not account for combined effects of climate change and land use of bioenergy policies may under- or overestimate impacts (de Chazal and Rounsevell 2009). Nevertheless, so far the scenario-based impact assessments of bioenergy have often ignored the simultaneous direct impacts of climate change on species distributions (but see Alkemade et al. 2009; Table 1). If the aim is to compare advantages and disadvantages of bioenergy, assessments should compare the impact of climate change in a business as usual scenario to the increased impact of mitigation action though reduced impact of climate change.

IAMs include changes in climatic indicators such as temperature. These indicators can be downscaled to the grid or regional levels using pre-existing climate runs. For biodiversity at the local scale, however, it is also important to have insight into variation in temperature and moisture (Austin 2002; Barry and Elith 2006). While there are also techniques to derive those, the uncertainties here are large. On the other hand, more specific predictions of regional climate change are becoming available from regional climatic circulation models for the new climate policy scenarios, also including mitigations scenarios. Many studies have therefore estimated climate impacts separately from those of land-use models. Given the large uncertainty in regional climate predictions, sophisticated biodiversity assessments might consider exploring a wide range of climate scenarios-either coming directly from climate models or developed by downscaling IAM projections. It should also be noted that land-use changes themselves may cause local climate change (e.g. via albedo). As these are not covered in existing projections in climate models or in downscaling techniques, it is useful to consider whether, in a specific study, land-use changes may be so large that these local impacts cannot be ignored.

Changes in land use can result in changes in the extent, spatial configuration and quality of suitable habitat. From the point of view of biodiversity assessment, land-use scenarios should be able to quantify the consequences of policy action in terms of habitat availability, quality and structure with those indicators which have been identified as key for biodiversity impacts in empirical studies. Ideally, the relationship between integrated climate and land- use scenarios and biodiversity assessments should be twofold. On one hand, scenarios should output relevant data for biodiversity assessments; on the other hand, biodiversity assessments should inform scenario planning so that alternative policy scenarios could be evaluated.

\section{Key limitations of global land-use scenarios from the perspective of biodiversity assessments}

Land-use scenarios produced by IAMs are appealing tools for biodiversity assessments, because they provide global projections based on relevant policy storylines. However, as the models were originally built to answer a different set of questions, they have limitations to the questions they can address in context of biodiversity assessment. In this section, the outputs of IAMs are assessed in light of the data requirements for biodiversity assessments as outlined above (see Fig. 1 for a summary of the empirical evidence and links to IAM outputs).

IAMs produce future maps of land use often based on rather simplified rules (for food crops and bioenergy crops). Such rules include the potential and costs for energy crops and availability of suitable land (e.g. in current output of the IMAGE framework, bioenergy allocation is in standard scenarios allocated to high-yield grid cells that are either abandoned agricultural land, natural grasslands and savannah; Hoogwijk 2004). More detailed scenarios could be built regionally, based on more detailed policy storylines. For example, the European Union targets for renewable energy and member state strategies for meeting these targets could inform the regional scenario work on more detailed distribution of bioenergy demand and inform policy planning about potential sustainability conflicts, based on which policy could be revised. A challenge is that current obligations exist only up to 2020, and more longterm strategies vary both in time span and level of detail among member states of the EU.

Another key problem for informing biodiversity conservation in practice is that the resolution of the spatial data is incompatible with the level of detail that is needed. Most global models use an aggregation level of $0.5 \times 0.5$ degree or higher-this resolution is too coarse for making conclusions of many relevant biodiversity impacts identified in empirical studies. Attempts have been made to develop more detailed scenarios. An example of this are the $1 \times 1 \mathrm{~km}^{2}$ projections of agricultural land use up to 2030 developed using a biofuel crop allocation model that accounts for logistics between fields and refineries (Hellmann and Verburg 2011). However, there is a clear tradeoff here between uncertainty (becoming increasingly important in the future) and the demand for detail in scenario description and variables. Hellmann and Verburg 
needed a detailed projection of biofuel production to justify their high spatial resolution. Still, high spatial resolution may result in a false sense of detail.

The current IMAGE scenarios encounter similar tradeoffs. Because downscaling projections with more detailed land cover can be useful for refining the quantitative assessment of impact, the IMAGE land-use scenarios have been downscaled from their native $30^{\prime}$ grid cell size to a $0.6^{\prime}$ resolution with more detailed land cover data for biodiversity assessments (Visconti et al. 2011). However, it does not necessarily increase the spatial accuracy, if the allocation rules are general and uncertainty is high. On the other hand, using detailed allocation rules instead of downscaling can increase the prediction's sensitivity to uncertainty in the assumptions, making the spatially detailed predictions highly uncertain. Over-reliance on uncertain predictions when making decisions can lead to misallocation of resources (Pilkey-Jarvis and Pilkey 2008).

Increasing the time horizon in land-use projections necessarily means trading off spatial resolution and increasing uncertainty. Investments in energy infrastructure are far-reaching; biomass-burning power plants built today are still online in 2050. Nevertheless, future land-use needs for bioenergy depend on developments in climatic suitability for biomass production and the realized energy portfolio. Uncertainty accumulates in predictions over time, which implies that scenarios cannot be interpreted as predictions of the future. Instead, scenarios can help identify potential problems in the developments they describe, and design policy through which those problems can be avoided. Accounting for the uncertainties is important, and robust policy would be an ideal objective. Identifying problems in bioenergy sustainability can be addressed, for example, by applying sustainability criteria that exclude unsustainable sources of biomass.

Empirical studies have identified the implications on landscape structure and management practices as important factors determining the impact of bioenergy on biodiversity (Londo et al. 2005; Rowe et al. 2011; Northrup et al. 2012; Fig. 1). Exploring land-use scenarios with varying landscape structure and management practices would be ideal, yet currently unfeasible over large spatial scales. In addition to high requirements for the land-use scenarios, such analyses are also demanding from the perspective of biodiversity data. Simulations in a virtual landscape can help overcome this problem and allow formulating policy recommendations (see Engel et al. 2012 for an example).

Another common limitation of land cover models is that forest age classes, deadwood availability and vertical structure are missing from most of them, even though these are critical determinants of habitat suitability for many forest species depending on old growth forest. The local negative impacts of energy harvesting of stumps and other residues have been well documented (Brin et al. 2012; Jonsell and Hansson 2011; Jonsell et al. 2007; Lassauce et al. 2012; Sullivan et al. 2011; Victorsson and Jonsell 2012; Åström et al. 2005; see Fig. 1). Management practices in managed forests determine those important structural features. However, global land-use scenarios often do not explore management practices, and they do not explicitly allocate residue uptake or traditional bioenergy (van Vuuren et al. 2010). Furthermore, most scenarios do not account for forest degradation. This is a limitation to assessing changes in habitat suitability for forest species in bioenergy scenarios which include energy harvesting of logging residues or other forest resources. More specific modelling approaches are necessary-and available-to address this issue in more detail (Sacchelli et al. 2013).

IAMs allocate land use based on predefined sets of criteria, such as climatic suitability, population density and demand for resources. The projections are based on scenario-specific assumptions on drivers and constraints such as energy resources, trade, technological development and environmental conditions, but often disregard biodiversity conservation opportunities and needs (Davis et al. 2011). Biodiversity considerations can be included in these rules. For example, IMAGE projections allow for estimating future bioenergy potential under various natural constraints such as existing protected areas (van Vuuren et al. 2009). However, current conservation measures are not sufficient to halt the ongoing loss of biodiversity (Butchart et al. 2010), and countries of the world have agreed to increase the coverage of terrestrial protected areas to $17 \%$ from the current $13 \%$ already by 2020 (UNFCCC 2010). If such necessary near future protected area expansions are not accounted for when considering restrictions to the allocation of bioenergy areas, the scenarios remain unrealistic, adding further challenges to the conservation of biodiversity. Moreover, further increases in the coverage of protected areas will be necessary to meet biodiversity targets, especially as the ranges of species are predicted to shift as a response to climate change (Araújo et al. 2011; Hannah et al. 2007; Hannah et al. 2002; Heller and Zavaleta 2009). More generally, several studies recommend mainstreaming biodiversity conservation throughout land-use planning so that the landscape managed for economic purposes would remain biodiversity friendly (Hannah et al. 2002; Noss 2001; Wilson and Piper, 2008). Neither conservation value of sites nor future conservation needs are currently included in the IAM-based land-use scenarios.

The extent and location of land set aside for conservation purposes affects the global bioenergy potential. A scenario where $20 \%$ of each biome would be protected for biodiversity, adding up to $25 \%$ of the terrestrial land area, implies a $21 \%$ lower bioenergy potential than a scenario where only existing protected areas are excluded from the 
estimates (van Vuuren et al. 2009). The extent of protected areas needed to halt biodiversity loss is a central debate in conservation science, and protecting up to $50 \%$ of land area has been suggested in the literature (Noss et al. 2012). However, the question cannot be answered through science alone, as it entails accepting certain risk levels and levels of loss, and requires therefore value judgments as well (Wilhere 2008). Identifying priority areas for conservation can take place in a systematic planning framework (Margules and Pressey 2000) or by other means of prioritizing areas depending on objectives and target biodiversity features in question (Brooks et al. 2006). Exploring the potential conflict between conservation needs and bioenergy production, and the effect of enhanced conservation action for bioenergy potential, would make the necessary trade-offs and compromises more transparent and open for debate. Moreover, it is not clear how bioenergy potential varies between different management regimes. Would environmental considerations reduce the productivity of lands allocated to energy biomass production? Research could approach these questions from both global and more localized perspectives.

Global scenarios are useful for policy planning at a regional or national level, as they serve as starting points for further allocating land use based on more detailed information about regional or national policy objectives and restrictions. However, for predicting the allocation in more detail within a country or region, different types of scenarios and allocation rules are needed. In the next section, we provide recommendations for using and developing IAMs from the perspective of biodiversity assessments and conservation.

\section{Conclusions and recommendations}

Based on our synthesis of the existing literature, we derive recommendations for (1) selecting and developing modelling tools and practice based on the research question at hand, (2) using the existing IAM projections in biodiversity assessments to achieve meaningful and robust outcomes, (3) using biodiversity information in land-use planning and (4) using the available scenarios in regional bioenergy planning. Overall, we propose tighter integration of conservation values and needs as well as climate change impacts to land-use allocation and biodiversity impact assessments (Fig. 2).

The choice of appropriate research tool depends on the research question and scale. IAMs have been designed to address questions at global or large regional scales, and are therefore appropriate tools for analysing questions related to aggregate impacts of alternative policy developments, broad impacts of bioenergy on biodiversity and issues

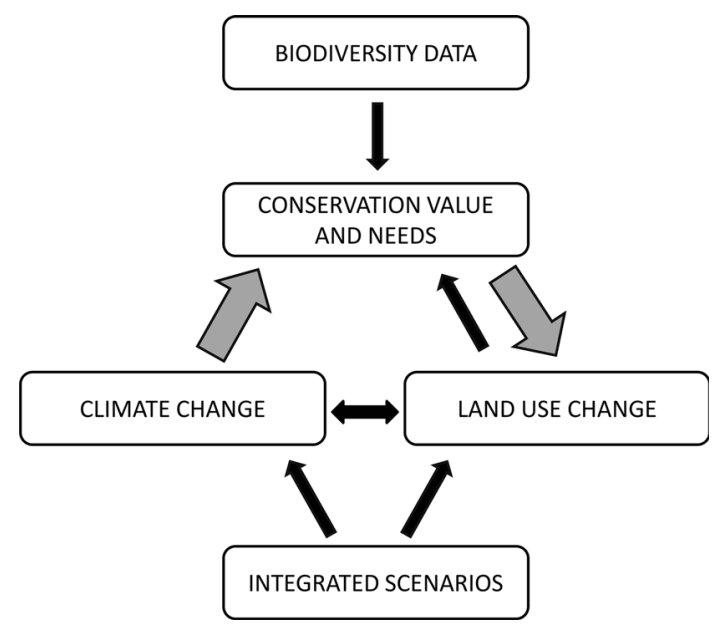

Fig. 2 Links between biodiversity data, conservation value and needs, land-use change and climate change. Black arrows represent links in current assessments, thick grey arrows present links that should be better integrated in the assessment framework

related to indirect land use. For questions at local scale, however, local land-use models might be more suitable. Tools designed for different scales could be used in combination. IAMs can, for example, provide information on boundary conditions for regional level models that have a higher spatial resolution. These regional tools can subsequently account for habitat quality implications of harvesting logging residues for energy production and integrating current and future conservation values and needs in the land-use allocation rules. We argue that landuse scenarios could be adjusted to better meet the needs of biodiversity impact assessments, if their spatial accuracy would be increased through considerations of regional processes (Hellmann and Verburg 2011) also in the longerterm projections. However, increasing spatial accuracy of the land-use scenarios would need to happen through more detailed policy storylines and processes at a relevant scale. This could mean, for example, that a model with more detailed input information and higher spatial resolution would be applied to the boundary conditions set by a global, more general model. When spatial accuracy is increased, also the sensitivity of predictions to errors increases, so the predictions should be accompanied by quantified estimations of uncertainty. Careful consideration of the trade-off between spatial resolution of scenarios and time scale is necessary to ensure that conclusions based on scenarios are robust to, or properly acknowledge, the associated uncertainty.

Assessment of bioenergy impacts on biodiversity would gain significantly, if it was possible to assess the impacts of changing forestry practices due to energy harvesting of logging residues. Existing empirical evidence of the biodiversity impacts could help in formulating the relationship. 
Current and future conservation value of sites could be integrated in the set of land-use allocation rules so that the land-use allocation algorithm would avoid assigning cells to bioenergy feedstock production or other intensive management when they contain high value for biodiversity conservation. Comparing land-use scenarios with and without trade-offs could be used to assess how different considerations affect the economic, ecological and social costs and benefits of different scenarios.

We believe that, even though IAMs were not developed for biodiversity assessments, they provide meaningful input for such assessments. However, such scenarios should not be used to predict consequences for biodiversity disregarding the direct impacts of climate change (de Chazal and Rounsevell 2009). Despite uncertainty associated with bioclimatic envelope models (Buisson et al. 2010; Garcia et al. 2011; Pearson and Dawson 2003), climate change impacts on biodiversity have been predicted to be substantial, and worryingly in line with observed ongoing biodiversity trends even though time lags in responses are not negligible (Bertrand et al. 2011; Devictor et al. 2012; Dullinger et al. 2012). In addition, when interpreting the impacts of bioenergy on species, habitats and conservation opportunities, it is important to bear in mind that not all bioenergy impacts can be explicitly inferred from IAM outputs. The most important limitation is the impact of energy harvesting of logging residues or associated impacts for forestry management practices.

Conservation value and need are currently not considered in the IAM framework. To minimize conflicts between biodiversity conservation and bioenergy, biodiversity information could be used to inform the allocation of bioenergy cells. When potential bioenergy feedstock productivity for each site can be calculated, spatial optimization tools can also be used to allocate bioenergy production so that bioenergy targets are met with the least possible impact on biodiversity (Stoms et al. 2012). Such approaches are current practice in modern conservation planning where land-use conflicts are accounted for. Trade-offs between optimal allocation of bioenergy feedstock production and conservation could also be quantified with a replacement cost analysis (Cabeza and Moilanen, 2006; Moilanen et al. 2009).

Global scenarios of environmental change can quantify the magnitude of the impact on land-use change at a regional level, and thereby inform the debate on how mitigation actions affect adaptation opportunities and needs. Furthermore, they can help identifying potential conflicts between different goals. This information is valuable for planning policy to provide the conflict-avoiding guidance and steering. While those who contribute to developing and implementing complex predictive models are well aware of their limitations and associated uncertainties, those who use the outputs as policy support may not be that familiar with the proper interpretations.

Regional policy planning can gain from global land-use scenarios, even if the policy storylines or level of spatial detail do not account for specific regional policy goals and measures. They provide a starting point for more detailed assessment: how would different land-use demands distribute further in a regional policy context? Identifying areas with high risk of conflict between biodiversity value and bioenergy production can help formulate policy in such a way that it steers bioenergy production away from sites where harm on biodiversity would be substantial. For example, the European Union legislation excludes bioenergy production in protected areas, primary forests or highly diverse grasslands (European Parliament 2009), but does not define what high biodiversity value means (Eickhout et al. 2008). While the existing scenarios account for current protected areas (van Vuuren et al. 2010; Sacchelli et al. 2013), policy must acknowledge the insufficiency of current conservation measures to halt the loss of biodiversity and allow adaptation to climate change.

Acknowledgments We wish to thank Andries Hof for insights and comments on the manuscript as well as Mikael Hildén, Hannu Pietiäinen and Hanna Tuomisto for discussions which provided inspiration for this manuscript. The feedback from two anonymous reviewers has been useful for developing the manuscript. LM acknowledges LUOVA Graduate School for funding. MC, DvV and LM acknowledge funding from European Union Framework Programme 7 project RESPONSES (Grant Agreement No. 244092).

\section{References}

Alkemade R, van Oorschot M, Miles L et al (2009) GLOBIO3: a framework to investigate options for reducing global terrestrial biodiversity loss. Ecosystems 12:374-390. doi:10.1007/s10021009-9229-5

Araújo MB, Alagador D, Cabeza M et al (2011) Climate change threatens European conservation areas. Ecol Lett 14:484-492. doi:10.1111/j.1461-0248.2011.01610.x

Åström M, Dynesius M, Hylander K, Nilsson C (2005) Effects of slash harvest on bryophytes and vascular plants in southern boreal forest clear-cuts. J Appl Ecol 42:1194-1202. doi:10.1111/ j.1365-2664.2005.01087.x

Austin M (2002) Spatial prediction of species distribution: an interface between ecological theory and statistical modelling. Ecol Model 157:101-118. doi:10.1016/S0304-3800(02)00205-3

Barbet-Massin M, Thuiller W, Jiguet F (2012) The fate of European breeding birds under climate, land-use and dispersal scenarios. Glob Change Biol 18:881-890. doi:10.1111/j.1365-2486.2011.02552.x

Barry S, Elith J (2006) Error and uncertainty in habitat models. J Appl Ecol 43:413-423. doi:10.1111/j.1365-2664.2006.01136.x

Baum S, Bolte A, Weih M (2012) Short rotation coppice (SRC) plantations provide additional habitats for vascular plant species in agricultural mosaic landscapes. Bioenergy Res 5:573-583. doi:10.1007/s12155-012-9195-1

Bellard C, Bertelsmeier C, Leadley P et al (2012) Impacts of climate change on the future of biodiversity. Ecol Lett 15:365-377. doi: 10.1111/j.1461-0248.2011.01736.x 
Bertrand R, Lenoir J, Piedallu C et al (2011) Changes in plant community composition lag behind climate warming in lowland forests. Nature 479:517-520. doi:10.1038/nature10548

Brin A, Bouget C, Valladares L, Brustel H (2012) Are stumps important for the conservation of saproxylic beetles in managed forests?-insights from a comparison of assemblages on logs and stumps in oak-dominated forests and pine plantations. Insect Conservation and Diversity (article in press). doi:10.1111/ j.1752-4598.2012.00209.x

Brooks TM, Mittermeier RA, Da Fonseca GAB et al (2006) Global biodiversity conservation priorities. Science 313:58-61. doi: 10.1126/science. 1127609

Buisson L, Thuiller W, Casajus N et al (2010) Uncertainty in ensemble forecasting of species distribution. Glob Change Biol 16:1145-1157. doi:10.1111/j.1365-2486.2009.02000.x

Butchart SHM, Walpole M, Collen B, et al. (2010) Global biodiversity: indicators of recent declines. Science (New York, NY) 328:1164-1168. doi:10.1126/science. 1187512

Cabeza M, Moilanen A (2006) Replacement cost: a practical measure of site value for cost-effective reserve planning. Biol Conserv 132:336-342. doi:10.1016/j.biocon.2006.04.025

CBD (2010) Global Biodiversity Outlook 3. Secr Conv Biol Divers Montr. doi:10.1093/aje/kwq338

Chazal J, Rounsevell MDA (2009) Land-use and climate change within assessments of biodiversity change: a review. Glob Environ Change 19:306-315. doi:10.1016/j.gloenvcha.2008.09.007

Chen I-C, Hill JK, Ohlemüller R, et al. (2011) Rapid range shifts of species associated with high levels of climate warming. Science (New York, NY) 333:1024-1026. doi:10.1126/science.120 6432

Creutzig F, Popp A, Plevin R et al (2012) Reconciling top-down and bottom-up modelling on future bioenergy deployment. Nat Clim Change 2:320-327. doi:10.1038/nclimate1416

Dahlberg A, Thor G, Allmer J et al (2011) Modelled impact of Norway spruce logging residue extraction on biodiversity in Sweden. Can J For Res-Rev Canadienne De Recherche Forestiere 41:1220-1232. doi:10.1139/x11-034

Danielsen F, Beukema H, Burgess ND, Parish F, Brühl CA, Donald PF, Murdiyarso D, Phalan B, Reijnders L, Struebig M, Fitzherbert EB (2009) Biofuel plantations on forested lands: double jeopardy for biodiversity and climate. Conserv Biol 24:348-358. doi:10.1111/j.1523-1739.2008.01096.x

Davis SC, House JI, Diaz-Chavez RA et al (2011) How can land-use modelling tools inform bioenergy policies? Interface Focus 1:212-223. doi:10.1098/rsfs.2010.0023

Dawson TP, Jackson ST, House JI et al (2011) Beyond predictions: biodiversity conservation in a changing climate. Science 332:53-58. doi:10.1126/science. 1200303

Devictor V, van Swaay C, Brereton T et al (2012) Differences in the climatic debts of birds and butterflies at a continental scale. Nat Clim Change 2:121-124. doi:10.1038/nclimate1347

Dhondt AA, Wrege PH, Sydenstricker KV, Cerretani J (2004) Clone preference by nesting birds in short-rotation coppice plantations in central and western New York. Biomass Bioenergy 27:429-435. doi:10.1016/j.biombioe.2004.05.001

Dornburg V, van Vuuren DP, van de Ven G et al (2010) Bioenergy revisited: key factors in global potentials of bioenergy. Energy Environ Sci 3:258-267. doi:10.1039/c003390c

Dornburg V, Faaij APC, Verweij P, et al. (2012) Assessment of global biomass potentials and their links to food, water, biodiversity, energy demand and economy. Climate change scientific assessment and policy analysis. Biomass Assessment Main report. Policy 1-108

Dullinger S, Gattringer A, Thuiller W et al (2012) Extinction debt of high-mountain plants under twenty-first-century climate change. Nat Clim Change 2:1-4. doi:10.1038/nclimate1514
Eggers J, Troltzsch K, Falcucci A et al (2009) Is biofuel policy harming biodiversity in Europe? Global Change Biol Bioenergy 1:18-34. doi:10.1111/j.1757-1707.2009.01002.x

Eickhout B, van den Bron GJ, Notenboom J, et al (2008) Local and global consequences of the EU renewable directive for biofuels. Assessment 1-70

Engel J, Huth A, Frank K (2012) Bioenergy production and Skylark (Alauda arvensis) population abundance - a modelling approach for the analysis of land-use change impacts and conservation options. Global Change Biol Bioenergy 4:713-727. doi:10.1111/ j.1757-1707.2012.01170.x

European Parliament (2009) Directive 2009/28/EC of the European Parliament and of the Council of 23 April 2009 on the promotion of the use of energy from renewable sources and amending and subsequently repealing Directives 2001/77/EC and 2003/30/EC

Fargione J, Hill J, Tilman D, et al (2008) Land clearing and the biofuel carbon debt. Science (New York, NY) 319:1235-1238. doi:10.1126/science. 1152747

Felten D, Emmerling C (2011) Effects of bioenergy crop cultivation on earthworm communities-A comparative study of perennial (Miscanthus) and annual crops with consideration of graded land-use intensity. Appl Soil Ecol 49:167-177. doi:10.1016/ j.apsoil.2011.06.001

Franklin J (2009) Mapping species distributions: spatial inference and prediction. Cambridge University Press, New York

Fry DA, Slater FM (2011) Early rotation short rotation willow coppice as a winter food resource for birds. Biomass Bioenergy 35:2545-2553. doi:10.1016/j.biombioe.2011.02.016

Garcia RA, Burgess ND, Cabeza M et al (2011) Exploring consensus in 21st century projections of climatically suitable areas for African vertebrates. Global Change Biol 18:1253-1269. doi: 10.1111/j.1365-2486.2011.02605.x

Gaucherel C, Griffon S, Misson L, Houet T (2009) Combining process-based models for future biomass assessment at landscape scale. Landsc Ecol 25:201-215. doi:10.1007/s10980-0099400-6

Hannah L, Midgley GF, Lovejoy T et al (2002) Conservation of biodiversity in a changing climate. Conserv Biol 16:264-268. doi:10.1046/j.1523-1739.2002.00465.x

Hannah L, Midgley G, Andelman S et al (2007) Protected area needs in a changing climate. Frontiers Ecol Environ 5:131-138. doi: 10.1016/j.biombioe.2011.02.016

Hanski I, Ovaskainen O (2003) Metapopulation theory for fragmented landscapes. Theor Popul Biol 64:119-127. doi:10.1016/S00405809(03)00022-4

Harrison T, Berenbaum MR (2012) Moth diversity in three biofuel crops and native prairie in Illinois. Insect Science (article in press). doi:10.1111/j.1744-7917.2012.01530.x

Haughton AJ, Bond AJ, Lovett AA, Dockerty T, Sunnenberg G, Clark SJ, Bohan DA, Sage RB, Mallott MD, Mallott VE, Cunningham MD, Riche AB, Shield IF, Finch JW, Turner MM, Karp A (2009) A novel, integrated approach to assessing social, economic and environmental implications of changing rural land-use: a case study of perennial biomass crops. J Appl Ecol 46:315-322. doi: 10.1111/j.1365-2664.2009.01623.x

Heller NE, Zavaleta ES (2009) Biodiversity management in the face of climate change: a review of 22 years of recommendations. Biol Conserv 142:14-32. doi:10.1016/j.biocon.2008.10.006

Hellmann F, Verburg PH (2010) Impact assessment of the European biofuel directive on land use and biodiversity. J Environ Manag 91:1389-1396. doi:10.1016/j.jenvman.2010.02.022

Hellmann F, Verburg PH (2011) Spatially explicit modelling of biofuel crops in Europe. Biomass Bioenergy 35:2411-2424. doi: 10.1016/j.biombioe.2008.09.003

Hodgson JA, Thomas CD, Wintle BA, Moilanen A (2009) Climate change, connectivity and conservation decision making: back to 
basics. J Appl Ecol 46:964-969. doi:10.1111/j.1365-2664.2009. 01695.x

Hoogwijk MM (2004) On the global and regional potential of renewable energy sources. Dissertation, University of Utrecht

Hurtt GC, Chini LP, Frolking S, Betts RA, Feddema J, Fischer G, Fisk JP, Hibbard K, Houghton RA, Janetos A, Jones CD, Kindermann G, Kinoshita T, Klein Goldewijk K, Riahi K, Shevliakova E, Smith S, Stehfest E, Thomson A, Thornton P, van Vuuren DP, Wang YP (2011) Harmonization of land-use scenarios for the period 1500-2100: 600 years of global gridded annual land-use transitions, wood harvest, and resulting secondary lands. Clim Change 109:117-161. doi:10.1007/s10584-011-0153-2

IPCC (2000) Special report on emission scenarios. In: Nakicenovic N, Swart R (eds) Cambridge University Press, Cambridge, pp 570. http://www.ipcc.ch/ipccreports/sres/emission/index.htm

IPCC (2011) IPCC special report on renewable energy sources and climate change mitigation. In: Edenhofer O, Pichs-Madruga R, Sokona Y, Seyboth K, Matschoss P, Kadner S, Zwickel T, Eickemeier P, Hansen G, Schlömer S, von Stechow C (eds) Prepared by Working Group III of the intergovernmental panel on climate change. Cambridge University Press, Cambridge, New York, pp 1075. http://srren.ipcc-wg3.de/report

Jackson RB, Jobbágy EG, Avissar R, et al (2005) Trading water for carbon with biological carbon sequestration. Science (New York, NY) 310:1944-1947. doi:10.1126/science.1119282

Jonsell M, Hansson J (2011) Logs and stumps in clearcuts support similar saproxylic beetle diversity: implications for bioenergy harvest. Silva Fennica 45:1053-1064

Jonsell M, Hansson J, Wedmo L (2007) Diversity of saproxylic beetle species in logging residues in Sweden-comparisons between tree species and diameters. Biol Conserv 138:89-99. doi: 10.1016/j.biocon.2007.04.003

Langeveld H, Quist-Wessel F, Dimitriou I, Aronsson P, Baum C, Schulz U, Bolte A, Baum S, Koehn J, Weih M, Gruss H, Leinweber P, Lamersdorf N, Schmidt-Walter P, Berndes G (2012) Assessing environmental impacts of short rotation coppice (SRC) expansion: model definition and preliminary results. Bioenergy Res 5:621-635. doi:10.1007/s12155-012-9235-x

Lassauce A, Lieutier F, Bouget C (2012) Woodfuel harvesting and biodiversity conservation in temperate forests: effects of logging residue characteristics on saproxylic beetle assemblages. Biol Conserv 147:204-212. doi:10.1016/j.biocon.2012.01.001

Londo M, Dekker J, Terkeurs W (2005) Willow short-rotation coppice for energy and breeding birds: an exploration of potentials in relation to management. Biomass Bioenergy 28:281-293. doi:10.1016/j.biombioe.2004.06.007

Louette G, Maes D, Alkemade JRM et al (2010) BioScore-Costeffective assessment of policy impact on biodiversity using species sensitivity scores. J Nat Conserv 18:142-148. doi: 10.1016/j.jnc.2009.08.002

Margules CR, Pressey RL (2000) Systematic conservation planning. Nature 405:243-253. doi:10.1038/35012251

Meehan TD, Hurlbert AH, Gratton C (2010) Bird communities in future bioenergy landscapes of the upper Midwest. Proceed Nat Acad Sci USA 107:18533-18538. doi:10.1073/pnas.1008475107

Millennium Ecosystem Assessment (2005) Ecosystems and human well-being: biodiversity synthesis. World Resources Institute, Washington DC

MNP (2006) Integrated modelling of global environmental changean overview of IMAGE 2.4. In: Bouwman AF, Kram T, Klein Goldewijk K (eds) Netherlands Environmental Assessment Agency (MNP), Bilthoven

Moilanen A, Arponen A, Stokland J, Cabeza M (2009) Assessing replacement cost of conservation areas: how does habitat loss influence priorities? Biol Conserv 142:575-585. doi:10.1016/ j.biocon.2008.11.011
Moss RH, Edmonds JA, Hibbard KA et al (2010) The next generation of scenarios for climate change research and assessment. Nature 463:747-756. doi:10.1038/nature08823

Myers MC, Hoksch BJ, Mason JT (2012) Butterfly response to floral resources during early establishment at a heterogeneous prairie biomass production site in Iowa, USA. J Insect Conserv 16:457-472. doi:10.1007/s10841-011-9433-4

Nilsson C, Berggren K (2000) Alterations of riparian ecosystems caused by river regulation. Bioscience 50:783. doi:10.1641/ 0006-3568(2000)050[0783:AORECB]2.0.CO;2

Northrup JM, Wittemyer G, Regan H (2012) Characterising the impacts of emerging energy development on wildlife, with an eye towards mitigation. Ecol Lett 16:112-125. doi:10.1111/ele. 12009

Noss RF (2001) Beyond Kyoto? forest management in a time of rapid climate change. Conserv Biol 15:578-590. doi:10.1046/j.15231739.2001.015003578.x

Noss RF, Dobson AP, Baldwin R et al (2012) Bolder thinking for conservation. Conserv Biol 26:1-4. doi:10.1111/j.1523-1739. 2011.01738.x

OECD (2012) OECD environmental outlook to 2050. OECD Publishing

Parmesan C (2006) Ecological and evolutionary responses to recent climate change. Ann Rev Ecol Evol Syst 37:637-669. doi: 10.1146/annurev.ecolsys.37.091305.110100

Parson EA, Fisher-Vanden K (1997) Integrated assessment models of global climate change. Ann Rev Energy Environ 22:589-628. doi:10.1146/annurev.energy.22.1.589

Paterson JS, Araújo MB, Berry PM et al (2008) Mitigation, adaptation, and the threat to biodiversity. Conserv Biol 22:1352-1355. doi:10.1111/j.1523-1739.2008.01042.x

Pearson RG, Dawson TP (2003) Predicting the impacts of climate change on the distribution of species: are bioclimate envelope models useful? Glob Ecol Biogeogr 12:361-371. doi:10.1046/ j.1466-822X.2003.00042.x

Pereira HM, Leadley PW, Proença V, Alkemade R, Scharlemann JPW, Fernandez-Manjarrés JF, Araújo MB, Balvanera P, Biggs R, Cheung WWL, Chini L, David Cooper H, Gilman EL, Guénette S, Hurtt GC, Huntington HP, Mace GM, Oberdorff T, Revenga C, Rodrigues P, Scholes RJ, Sumaila UR, Walpole M (2010) Scenarios for global biodiversity in the 21 st century. Science 330:1496-1501. doi:10.1126/science.1196624

Pilkey-Jarvis L, Pilkey OH (2008) Useless arithmetic: ten points to ponder when using mathematical models in environmental decision making. Public Adm Rev 470-479

Plevin RJ, O'Hare M, Jones AD et al (2010) Greenhouse gas emissions from biofuels' indirect land use change are uncertain but may be much greater than previously estimated. Environ Sci Technol 44:8015-8021. doi:10.1021/es101946t

Questad EJ, Foster BL, Jog S, Kindscher K, Loring H (2011) Evaluating patterns of biodiversity in managed grasslands using spatial turnover metrics. Biol Conserv 144:1050-1058. doi: 10.1016/j.biocon.2010.12.024

Righelato R, Spracklen DV (2007) Carbon mitigation by biofuels or by saving and restoring forests? Science (New York, NY) 317:902. doi:10.1126/science.1141361

Robertson BA, Doran PJ, Loomis LR, Robertson JR, Schemske DW (2011a) Perennial biomass feedstocks enhance avian diversity. Glob Change Biol Bioenergy 3:235-246. doi:10.1111/j.17571707.2010.01080.x

Robertson BA, Doran PJ, Loomis ER, Robertson JR, Schemske DW (2011b) Avian use of perennial biomass feedstocks as postbreeding and migratory stopover habitat. PLoS ONE 6: e16941. doi:10.1371/journal.pone.0016941

Robertson BA, Porter C, Landis DA, Schemske DW (2012) Agroenergy crops influence the diversity, biomass, and guild 
structure of terrestrial arthropod communities. Bioenergy Res 5:179-188. doi:10.1111/j.1757-1707.2010.01080.x

Robertson BA, Landis DA, Sillett TS, Loomis ER, Rice RA (2013) Perennial agroenergy feedstocks as en route habitat for spring migratory birds. Bioenergy Res 6:210-311. doi:10.1007/ s12155-012-9258-3

Rose SK, Ahammad H, Eickhout B, Fisher B, Kurosawa A, Rao S, Riahi K, van Vuuren DP (2012) Land-based mitigation in climate stabilization. Energy Econom 34:365-380. doi:10.1016/ j.eneco.2011.06.004

Rowe RL, Hanley ME, Goulson D et al (2011) Potential benefits of commercial willow Short Rotation Coppice (SRC) for farm-scale plant and invertebrate communities in the agri-environment. Biomass Bioenergy 35:325-336. doi:10.1016/j.biombioe.2010. 08.046

Sacchelli S, Meo I, Paletto A (2013) Bioenergy production and forest multifunctionality? A trade-off analysis using multiscale GIS model in a case study in Italy. Appl Energy 104:10-20. doi: 10.1016/j.apenergy.2012.11.038

Searchinger TD, Hamburg SP, Melillo J et al (2009) Fixing a critical climate accounting error. Science 326:527-528. doi:10.1126/ science. 1178797

Stoms DM, Davis FW, Jenner MW et al (2012) Modeling wildlife and other trade-offs with biofuel crop production. Glob Change Biol Bioenergy 4:330-341. doi:10.1111/j.1757-1707.2011.01130.x

Sullivan TP, Sullivan DS, Lindgren PMF et al (2011) Bioenergy or biodiversity? Woody debris structures and maintenance of redbacked voles on clearcuts. Biomass Bioenergy 35:4390-4398. doi:10.1016/j.biombioe.2011.08.013

Thomson AM, Calvin KV, Smith SJ, Kyle GP, Volke A, Patel P, Delgado-Arias S, Bond-Lamberty B, Wise MA, Clarke LE, Edmonds JA (2011) RCP4.5: a pathway for stabilization of radiative forcing by 2100. Clim Change 109:77-94. doi:10.1007/ s10584-011-0151-4

Thuiller W (2004) Patterns and uncertainties of species' range shifts under climate change. Glob Change Biol 10:2020-2027. doi: 10.1111/j.1365-2486.2004.00859.x
UNFCCC (2010) The Cancun agreements: outcome of the work of the ad hoc working group on long-term cooperative action under the convention. Decision 1/CP.16

van Vuuren DP, Eickhout B, Lucas PL, den Elzen MGJ (2006a) Long-term multi-gas scenarios to stabilise radiative forcingexploring costs and benefits within an integrated assessment framework. Energy J 201-234

van Vuuren DP, Sala OE, Pereira HM (2006b) The future of vascular plant diversity under four global scenarios. Ecol Soc 11:25

van Vuuren DP, van Vliet J, Stehfest E (2009) Future bio-energy potential under various natural constraints. Energy Policy 37:4220-4230. doi:10.1016/j.enpol.2009.05.029

van Vuuren DP, Bellevrat E, Kitous A, Isaac M (2010) Bio-energy use and low stabilization scenarios. Energy J 31:193-222

van Vuuren DP, Stehfest E, den Elzen MGJ et al (2011) RCP2.6: exploring the possibility to keep global mean temperature increase below $2^{\circ} \mathrm{C}$. Clim Change 109:95-116. doi:10.1007/ s10584-011-0152-3

Victorsson J, Jonsell M (2012) Ecological traps and habitat loss, stump extraction and its effects on saproxylic beetles. Forest Ecol Manag 290:22-29. doi:10.1016/j.foreco.2012.06.057

Visconti P, Pressey RL, Giorgini D et al (2011) Future hotspots of terrestrial mammal loss. Philos Trans R Soc Lond Ser B Biol Sci 366:2693-2702. doi:10.1098/rstb.2011.0105

Werling BP, Meehan TD, Gratton C, Landis DA (2011) Influence of habitat and landscape perenniality on insect natural enemies in three candidate biofuel crops. Biol Control 59:304-312. doi: 10.1016/j.biocontrol.2011.06.014

Wilhere GF (2008) The how-much-is-enough myth. Conserv Biol 22:514-517. doi:10.1111/j.1523-1739.2008.00926.x

Wilson E, Piper J (2008) Spatial planning for biodiversity in Europe's changing climate. Eur Environ 18:135-151. doi:10.1002/eet

Wise M, Calvin K, Thomson A, Clarke L, Bond-Lamberty B, Sands R, Smith SJ, Janetos A, Edmonds J (2009) Implications of limiting $\mathrm{CO} 2$ concentrations for land use and energy. Science 324:1183-1186. doi:10.1126/science. 1168475 